
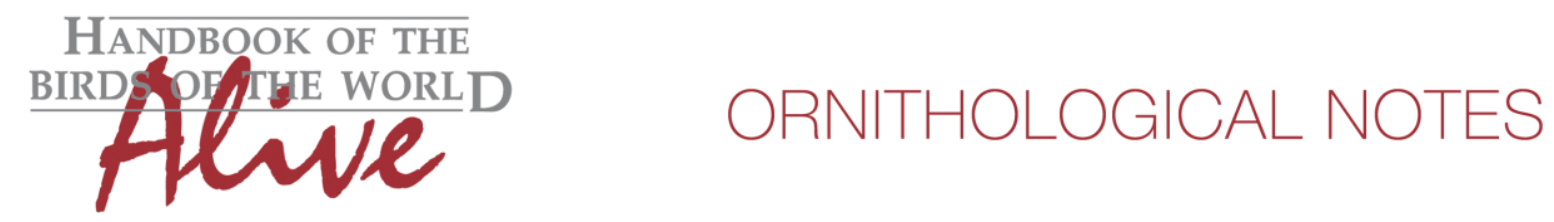

\title{
Notes on the vocalizations of Scrub Greenlet (Hylophilus flavipes)
}

Peter Boesman

In the following we briefly analyze and compare voice of the different races of Scrub Greenlet (Hylophilus flavipes). We also try to quantify the extent of any vocal differences using the criteria proposed by Tobias et al. (2010), as a support for taxonomic review. We have made use of sound recordings available on-line from Xeno Canto (XC).

Song phrase of all taxa is a single note repeated many times, such series initially increasing in amplitude, then stable for a while and ending abruptly. Single note is variable, but with a fairly simple note shape (usually upslurred). Song of Central American birds is clearly slowerpaced than South-American birds.

Some examples:

\section{Central America}

viridiflavus

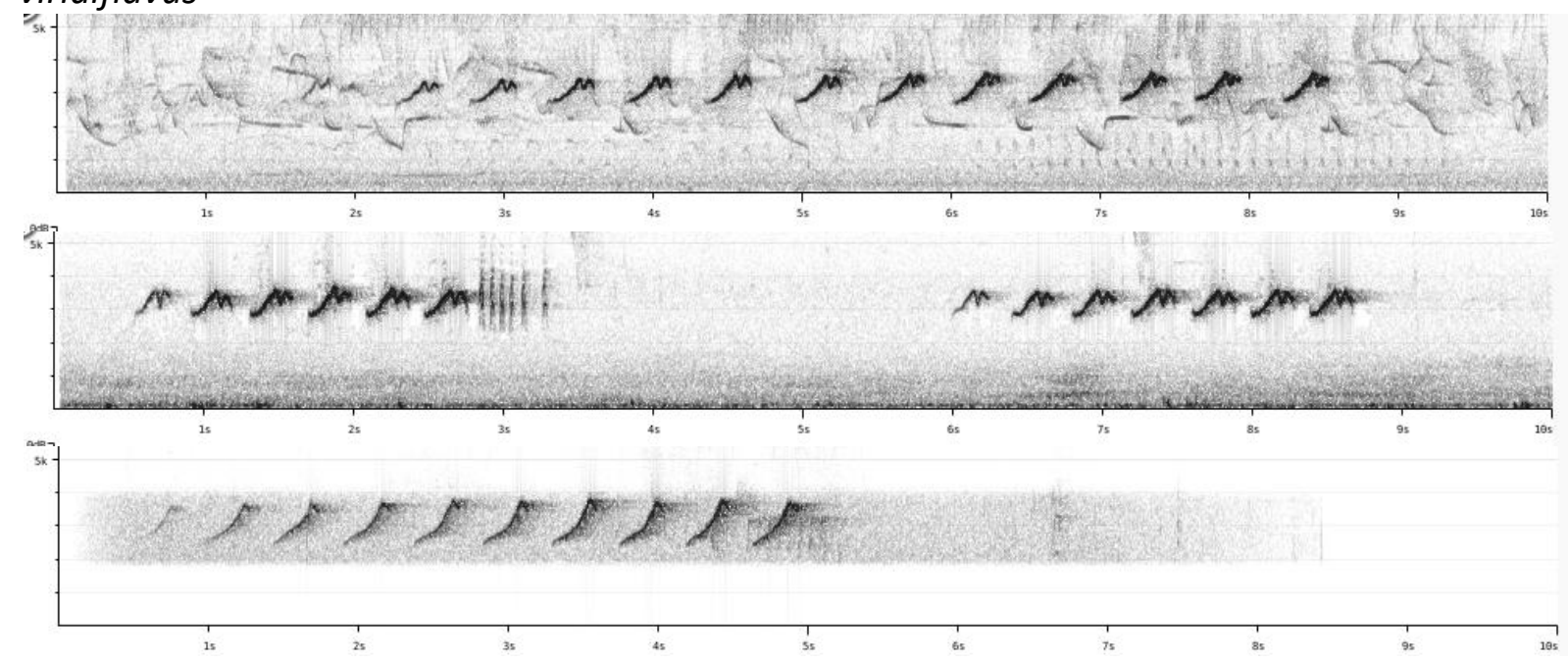

xuthus (Coiba Island)

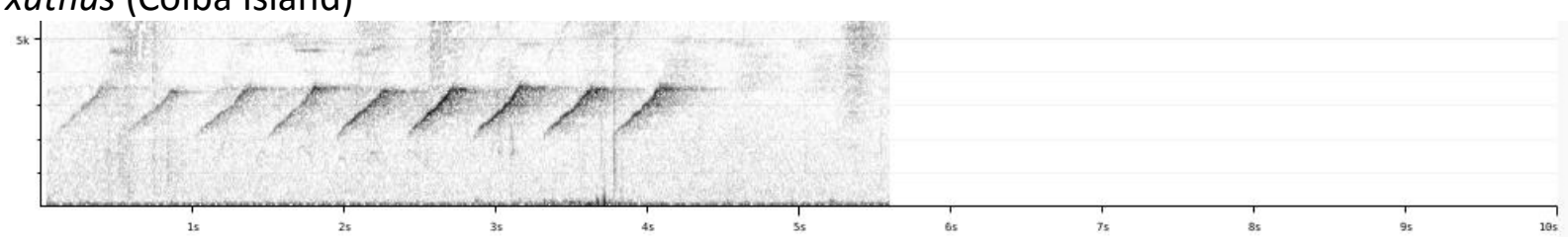

Basic sound parameters (continuous series of excited birds have not been included):

\# of notes

phrase length

Pace
6-12

$3.0-6.5 s$

0.43-0.52s (measured as period, duration between 2 consecutive notes) 


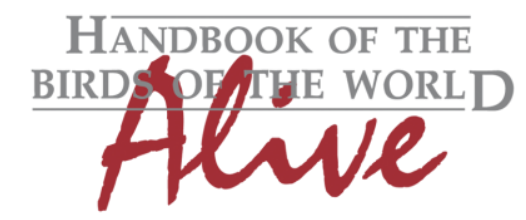

\section{ORNITHOLOGICAL NOTES}

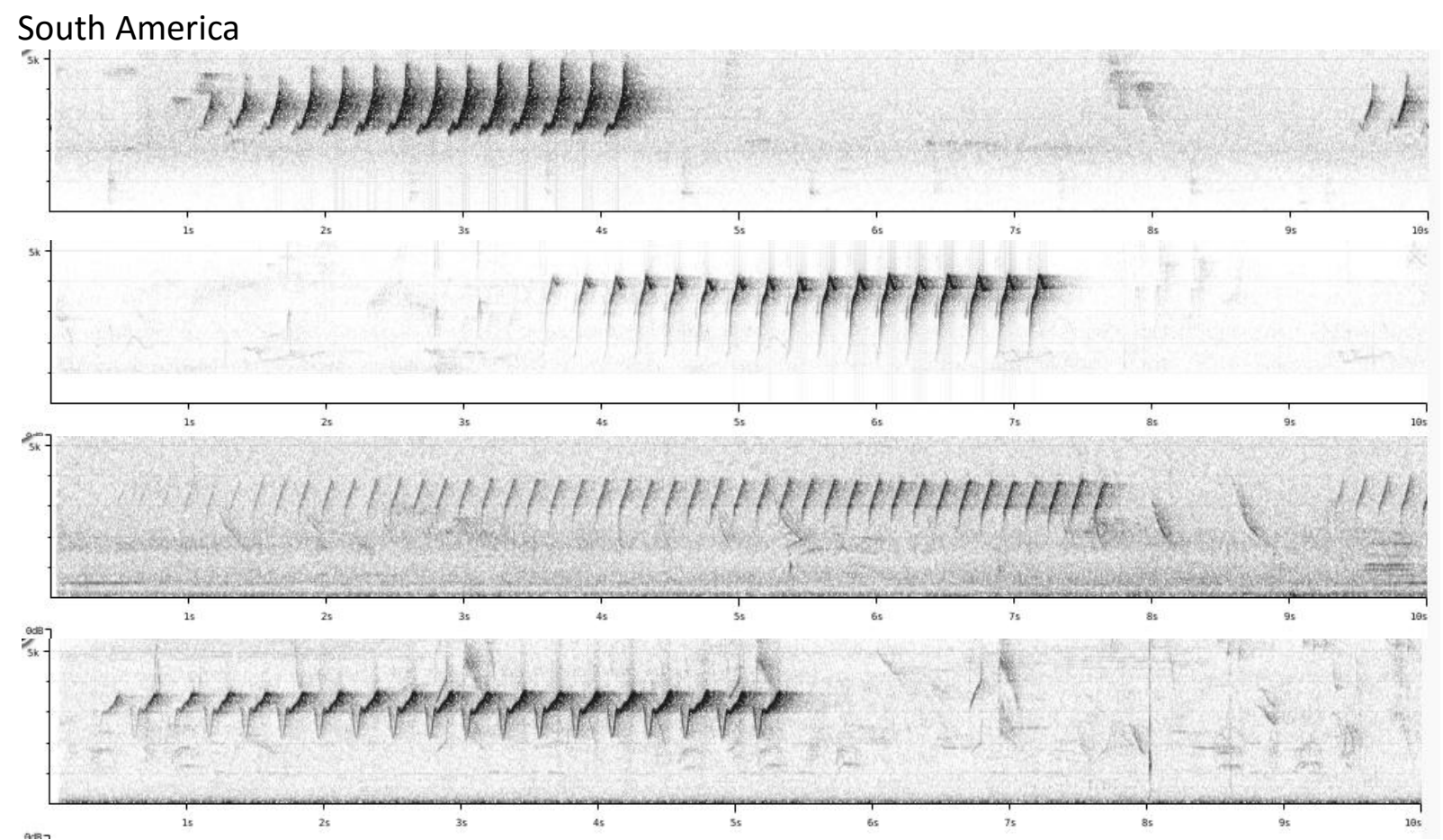

We haven't found any recordings of the race insularis from Tobago.

Basic sound parameters:

\# of notes $\quad 9-30$

phrase length $\quad 1.6-5.6 \mathrm{~s}$

Pace (period) $\quad 0.17-0.26 \mathrm{~s}$

The difference in vocal parameters is quite clear:

Birds of Central America sing a slower song (score 3) with fewer notes (score 1). When applying Tobias criteria, this would lead to a total vocal score of 4.

This note was finalized on 21st October 2015, using sound recordings available on-line at that moment. We would like to thank in particular the sound recordists who placed their recordings for this species on XC: Ken Allaire, Nick Athanas, Peter Boesman, David Edwards, Sergio Chapparo Herrera, Oswaldo Cortes, Jerome Fischer, Guillermo Funes, Wouter Halfwerk, Frank Lambert, Oscar Laverde, Bernabe Lopez-Lanus, Oscar Marín Gomez, Hans Matheve, Mike Nelson, Chris Parrish, Gary Stiles and Herman Van Oosten.

\section{References}

Tobias, J.A., Seddon, N., Spottiswoode, C.N., Pilgrim, J.D., Fishpool, L.D.C. \& Collar, N.J. (2010). Quantitative criteria for species delimitation. Ibis 152(4): 724-746.

\section{Recommended citation}

Boesman, P. (2016). Notes on the vocalizations of Scrub Greenlet (Hylophilus flavipes). HBW Alive Ornithological Note 174. In: Handbook of the Birds of the World Alive. Lynx Edicions, Barcelona. (retrieved from http://www.hbw.com/node/932107 on 21 August 2016). 